\title{
BIOAKTIVITAS ANTIOKSIDAN LOTION SENYAWA EKSOPOLISAKARIDA DARI MIKROALGA Spirulina sp.
}

\author{
Diah Astika Winahyu' ${ }^{1}$, Annisa Primadiamanti ${ }^{1}$ \\ ${ }^{1}$ Prodi Analisis Farmasi dan Makanan, Fakultas Kedokteran, Universitas Malahayati \\ astika.diah@gmail.com
}

\begin{tabular}{|l|}
\hline Artikel Info \\
Diterima \\
tanggal \\
27.08 .2020 \\
Disetujui \\
publikasi \\
tanggal \\
30.10 .2020 \\
Kata kunci : \\
antioksidan, \\
lotion, eksopo- \\
lisakarida, \\
Spirulina sp.
\end{tabular}

\begin{abstract}
ABSTRAK
Spirulina sp. merupakan jenis mikroalga yang mengandung komposisi senyawa kimia bermanfaat antara lain senyawa eksopolisakarida. Senyawa eksopolisakarida merupakan biopolimer yang memiliki aplikasi sangat luas, antara lain aplikasi penggunaan sebagai antioksidan, Spirulina sp. berpotensi dikembangkan sebagai bahan antioksidan secara alami. Penelitian ini bertujuan untuk melihat potensi bioaktivitas antioksidan senyawa eksopolisakarida Spirulina sp dalam sediaan lotion. Senyawa eksopolisakarida yang dihasilkan dari Spirulina sp. dianalisis gugus fungsi dengan FTIR, kemudian diformulasikan dalam sediaan lotion. Formulasi lotion kemudian dianalisis aktivitas antioksidan. Lotion hasil formulasi dengan senyawa eksopolisakarida dari mikroalga Spirulina sp. memiliki potensi sebagai lotion yang bersifat antioksidan. Nilai $\mathrm{IC}_{50}$ yang dihasilkan dari lotion F1 sebesar 42,429 ppm, F2 sebesar 35,986 ppm, F3 sebesar 29,726 ppm. Nilai $\mathrm{IC}_{50}$ lotion senyawa eksopolisakarida yang diperoleh termasuk jenis antioksidan yang memiliki aktivitas sangat kuat.
\end{abstract}

\begin{abstract}
Spirulina sp. is a type of microalgae that contains useful chemical compounds, including exopolysaccharide compounds. Exopolysaccharide compounds are biopolymers that have very wide applications, including applications as antioxidants, Spirulina sp. has the potential to be developed as an antioxidant ingredient naturally. This study aims to determine the potential for antioxidant bioactivity of the exopolysaccharide compound Spirulina sp in lotion preparation. Exopolysaccharide compounds produced from Spirulina sp. analyzed functional groups by FTIR, then formulated into lotions. The lotion formulation was then analyzed for its antioxidant activity. Lotion formulated with exopolysaccharide compounds from the microalgae Spirulina sp. has the potential as an antioxidant lotion. The IC50 value generated from the F1 lotion was 42.429 ppm, F2 was 35.986 ppm, F3 was 29.726 ppm. The IC50 value of the exopolysaccharide compound lotion obtained includes the type of antioxidant that has very strong activity.
\end{abstract}

\section{PENDAHULUAN}

Mikroalga merupakan mikroorganisme akuatik fotosintetik berukuran mikroskopik, yang dapat ditemukan di dalam air tawar dan air laut, paling tidak terdapat pada lokasi yang lembab, serta melakukan proses fotosintesis untuk membuat makanannya sendiri karena termasuk ke

doi: http://dx.doi.org/10.23960/aec.v5.i2.2020.p169-177 
dalam jenis makhluk hidup fotoautotrof(Anderson, 2005; Handayani \& Ariyanti, 2012).Mikroalga memiliki potensi cukup beragam meliputi bidangpertanian, obat-obatan, industri pangan, dan sebagai sumber bioenergi terbaharukan. Berdasarkan nutrisinya, mikroalga merupakan sumber mikronutrisi, vitamin dan trace elemen bagi komunitas perairan (Barsantiand Gualtieri. 2014; Richmond and Emeritus. 2013).

Spirulina sp. merupakan salah satu jenis mikroalga yang dapat dikultivasi pada media air tawar ataupun air laut. Hasil dari beberapa penelitian, menunjukkan bahwa Spirulinasp.merupakan salah satu spesies mikroalga yang berpotensi untuk dikembangkan.Hal ini disebabkan karena Spirulina sp. mengandung komposisi senyawa kimia dengan nilai gizi dan ekonomi tinggi, seperti mengandung protein, peptida, asam lemak esensial, vitamin, mineral, fikobiliprotein dan eksopolisakarida (Richmond and Emeritus. 2013; Vonshak, 2002).

Senyawa eksopolisakarida merupakan biopolimer yang memiliki aplikasi sangat luas, antara lain aplikasi penggunaan sebagai antioksidan, antikoagulan, antikanker dan bioflokulan (Nwodo et.al , 2012; Sajnaet.al, 2013). Keunggulan eksopolisakarida yang dihasilkan mikroalga dibandingkan dengan polimer sintetik yaitu bersifat aman, ekonomis untuk memproduksinya dan bersifat sinambung. Hal ini dikarenakan metode mengkultur mikroalga lebih mudah, cepat serta dapat dilakukan berkesinambungan tanpa batasan lokasi dan iklim setempat (Geresh et al., 2002; Harutoshi, 2013).

Berdasarkan uraian di atas, senyawa yang memiliki aktivitas antioksidan merupakan salah satu senyawa yang mendapat perhatian khusus untuk dapat digunakan. Telah diketahui bahwa senyawa antioksidan mampu menginaktivasi berkembangnya reaksi oksidasi dengan cara membentuk radikal. Antioksidan juga merupakan senyawa yang dapat menghambat reaksi oksidasi, dengan mengikat radikal bebas dan molekul yang sangat reaktif, sehingga dapat menghambat kerusakan sel (Samarakon and Jeon, 2012). Penelitian ini diharapkan menghasilkan senyawa eksopolisakarida dari Spirulina sp. yang memiliki aktivitas antioksidan dalam bentuk sediaan lotion yang dapat digunakan sebagai lotion yang bersifat antioksidan.

\section{METODE}

Alat dan Bahan

Alat utama yang digunakan dalam penelitian ini adalah Spektrofotometri UV-Vis (Agilent/Cary 100 , spatula, gunting, alat sentrifugasi (Hitachi CF16RX II), beaker glass neraca analitik (Wiggen 
hauser), alumunium foil, botol kaca hitam, freeze dryer (Scanlaf), corong, pipet tetes, labu ukur, gelas ukur tabung reaksi, kertas saring, vial gelap. Bahan yang digunakan adalah mikroalga Spirulina sp.,asam Askorbat, etanol 96\%, DPPH (Sigma aldrich), asam sterat, nipagin, nipasol, Trietilenamina (TEA), aquades, parafin cair, gliserin, setil alkohol.

\section{Prosedur}

\section{Kultivasi Spirulina sp.}

Mikroalga Spirulina sp. dikultivasi pada media Conway/Walne dengan kondisi kultivasi pH 7,5-8,5, suhu $25^{\circ} \mathrm{C}$, serta dilakukan pengamatan secara mikroskopik.

\section{Pemanenan dan Ekstraksi EPS}

Kultur Spirulina sp. dipisahkan dari biomasa Spirulina sp. menggunakan penyaring membran $0,2 \mu \mathrm{m}$ untuk mendapatkan filtrat Spirulina sp. Kultur dilakukan pemisahan antara biomassa dan filtrat. Filtrat kemudian ditambah dengan etanol 96\%, kemudian dilakukan sentrifugasi dengan kecepatan $8000 \mathrm{rpm}$ selama 15 menit pada suhu $4{ }^{\circ} \mathrm{C}$, sehingga didapat padatan eksopolisakarida, kemudian padatan dipisah dan dilakukan pengeringan menggunakan freeze dryer (Winahyu, 2017).

\section{Identifikasi Menggunakan Spektrofotometer FTIR}

Sampel senyawa eksopolisakarida yang telah dimurnikan kemudian di pres pada pelet $\mathrm{KBr}$ dengan perbandingan sampel dan $\mathrm{KBr} 1$ : 100. Background yang digunakan adalah pelet KBr murni. Spektrum direkam pada mode transmitan pada bilangan gelombang $4000-400 \mathrm{~cm}^{-1}$.

\section{Formulasi dan Pembuatan Lotion Senyawa Eksopolisakarida}

Tabel 1. Formulasi lotion senyawa eksopolisakarida

\begin{tabular}{lllccc}
\hline No & \multicolumn{1}{c}{ Nama Bahan } & Fungsi & $\begin{array}{c}\text { F1 0,5\% } \\
(\mathrm{b} / \mathrm{b})\end{array}$ & $\begin{array}{c}\text { F2 1\% } \\
(\mathrm{b} / \mathrm{b})\end{array}$ & $\begin{array}{c}\text { F3 1,5\% } \\
(\mathrm{b} / \mathrm{b})\end{array}$ \\
\hline 1 & Senyawa eksopolisakarida & Zat Aktif & 0,2 & 0,4 & 0,6 \\
2 & Asam stearat & Pengemulsi & 2 & 2 & 2 \\
3 & TEA & Pengemulsi & 0,5 & 0,5 & 0,5 \\
4 & Parafin Cair & Pelembab & 5 & 5 & 5 \\
5 & Setil Alkohol & Penstabil & 3 & 3 & 3 \\
6 & Gliserin & Humektan & 5 & 5 & 5 \\
7 & Metil Paraben & Pengawet & 0,1 & 0,1 & 0,1 \\
8 & Propil Paraben & Pengawet & 0,02 & 0,02 & 0,02 \\
9 & Akuades & Pelarut & Ad 50 & Ad 50 & Ad 50 \\
\hline
\end{tabular}

doi: http://dx.doi.org/10.23960/aec.v5.i2.2020.p169-177 
Semua bahan ditimbang sesuai dengan formulasi pembuatan lotion senyawa eksopolisakarida. Bahan-bahan fase minyak (asam stearat, setil alcohol, dan paraffin cair) dicampurkan lalu dipanaskan hingga suhu $70^{\circ} \mathrm{C}$ dengan menggunakan cawan porselin. Bahan-bahan fase cair (TEA, gliserin dan akuades) dicampur lalu dipanaskan dengan menggunakan gelas kimia. Fase minyak dan fase cair dicampurkan secara perlahan menggunakan mortar dan stemper yang telah dipanaskan terlebih dahulu hingga homogen. Metil paraben dan propil paraben ditambahkan lalu diaduk hingga homogen. Lalu ditambah ekstrak dan sisa akuades sedikit demi sedikit, diaduk sampai homogen. Sediaan lotion dimasukkan ke dalam wadah lotion.

\section{Uji Aktivitas Antioksidan}

\subsection{Pembuatan Larutan DPPH}

Sebanyak 10 mg DPPH dimasukkan kedalam labu takar $100 \mathrm{~mL}$ dan diencerkan dengan etanol $96 \%$ hingga tanda tera.

\subsection{Pembuatan Larutan Induk Vitamin C}

Sebanyak $5 \mathrm{mg}$ vitamin $\mathrm{C}$ ditimbang dan selanjutnya dimasukkan ke dalam labu takar $50 \mathrm{~mL}$ dan diencerkan dengan etanol 96\% hingga tanda tera.

\subsection{Pembuatan Larutan Induk Senyawa Eksopolisakarida}

Sebanyak 100 mg sampel hasil senyawa eksopolisakarida ditimbang dan selanjutnya ke dalam labu takar $100 \mathrm{~mL}$ dan diencerkan dengan etanol 96\% hingga tanda tera.

\subsection{Pembuatan Larutan Induk Sediaan Lotion Senyawa Eksopolisakarida}

Sampel ditimbang $500 \mathrm{mg}$ lalu dimasukkan kedalam labu ukur $100 \mathrm{~mL}$ dan diencerkan dengan etanol hingga tanda tera.

\subsection{Penentuan Panjang Gelombang Maksimum}

Larutan DPPH sebanyak 1,8 mL ditambahkan etanol 1,2 $\mathrm{mL}$ (3:2), dihomogenkan lalu diamati absorbansinya pada panjang gelombang 400-600 nm. Blanko digunakan etanol.

\subsection{Uji Kuantitatif Antioksidan}

Sampel dibuat dalam 4 konsentrasi masing-masing 40 ppm, 30 ppm, 20 ppm dan 10 ppm, lalu dipipetkan larutan DPPH sebanyak 1,8 ml dan larutan yang akan diuji 1,2 ml. Sampel diinkubasi, kemudian uji serapan dilakukan dengan menggunakan spektrofotometer UV-Vis dengan menggunakan panjang gelombang maksimum.

doi: http://dx.doi.org/10.23960/aec.v5.i2.2020.p169-177 


\subsection{Pengukuran $\mathrm{IC}_{50}$}

Nilai IC $_{50}$ dihitung berdasarkan persentase inhibisi terhadap radikal bebas DPPH dari masing-masing konsentrasi larutan dan didapatkan persamaan garis regresi linier $\mathrm{Y}=\mathrm{ax}+\mathrm{b}$. nilai y diganti dengan angka 50, sehingga didapatkan nilai x yang menunjukkan nilai $\mathrm{IC}_{50}$.

$\%$ Inhibisi ini dihitung dengan rumus :

$$
\% \text { Inhibisi }=\frac{\text { AbsorbansiKontrol }- \text { AbsorbansiSampe; }}{\text { AbsorbansiKontrol }}
$$

Keterangan : absorbansi kontrol = Nilai absorbansi DPPH

absorbansi sampel $=$ Nilai absorbansi sampel

\subsection{Perhitungan Nilai $\mathrm{IC}_{50}$}

Nilai $\mathrm{IC}_{50}$ antioksidan ekstrak senyawa eksopolisakarida dapat dihitung dengan menggunakan persamaan regresi :

$$
\mathrm{Y}=\mathrm{ax}+\mathrm{b}
$$

Keterangan :
$\mathrm{y}: \mathrm{IC}_{50}$
a: Slop b: Intersep
x: Kadar Larutan Sampel

\subsection{Analisis Data}

Berdasarkan klasifikasi Molyneux (2004) tingkat kekuatan antioksidan dengan metode DPPH dikategorikan sebagai berikut pada Tabel 2. :

Tabel 2. Tingkat kekuatan antioksidan

\begin{tabular}{cc}
\hline Intensitas & Nilai IC I0 $_{\mathbf{0}}$ \\
\hline Sangat kuat & $<50 \mu \mathrm{g} / \mathrm{mL}$ \\
Kuat & $50-100 \mu \mathrm{g} / \mathrm{mL}$ \\
Sedang & $101-150 \mu \mathrm{g} / \mathrm{mL}$ \\
Lemah & $>150 \mu \mathrm{g} / \mathrm{mL}$ \\
\hline
\end{tabular}

\section{HASIL DAN PEMBAHASAN}

\section{Pengamatan Mikroskop}

Hasil dari pengamatan mikroskop Spirulinasp. dengan perbesaran 400 kali, dapat dilihat pada Gambar 1. 


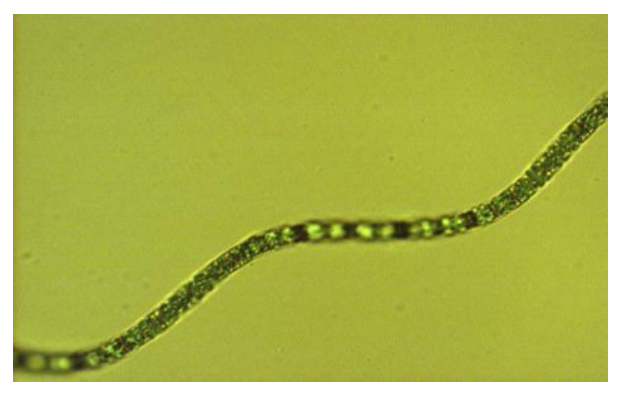

Gambar 1. Pengamatan mikroskop Spirulina sp. dengan perbesaran $400 \mathrm{X}$

\section{Pemanenan dan Ekstraksi Senyawa Eksopolisakarida}

Hasil dari kultivasi mikroalga Spirulina sp. dilakukan pemisahan antara biomassa dan filtrat menggunakan penyaring membran mikrofilter $0,2 \mu \mathrm{m}$. Prinsip filtrasi membran ini adalah dengan menyaring cairan sampel melewati saringan yang sangat tipis yang terbuat dari bahan sejenis selulosa. Penyaringan dengan membran mikrifilter bertujuan untuk memisahkan cairan filtrat hasil kulturasi Spirulina sp. dengan biomasa Spirulina sp. Filtrat hasil dari penyaringan kemudian ditambah dengan etanol 96\% sebanyak 2:1, lalu hasil filtrat berubah warna menjadi putih dan terjadi endapan putih. kemudian dilakukan sentrifugasi dengan kecepatan $8000 \mathrm{rpm}$ selama 15 menit pada suhu $4^{\circ} \mathrm{C}$. Sentrifugasi merupakan proses fraksinasi yang bertujuan untuk memisahkan senyawa eksopolisakarida dengan senyawa lainnya. Padatan hasil sentrifugasi kemudian dikeringkan menggunakan freeze dry hingga didapatkan ekstrak kasar senyawa eksopolisakarida yang kering seperti Gambar 2.

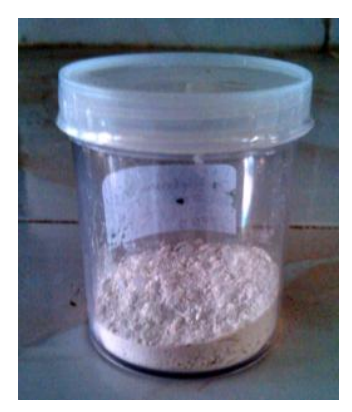

Gambar 2. Ekstrak kasar senyawa eksopolisakarida 


\section{Identifikasi Menggunakan Spektrofotometer FTIR}

Spektrum inframerah memberikan informasi lebih lengkap tentang gugus fungsional yang terkandung dalam struktur suatu senyawa. Spektrum FTIR ekstrak senyawaeksopolisakarida ditunjukkan pada Gambar 3.

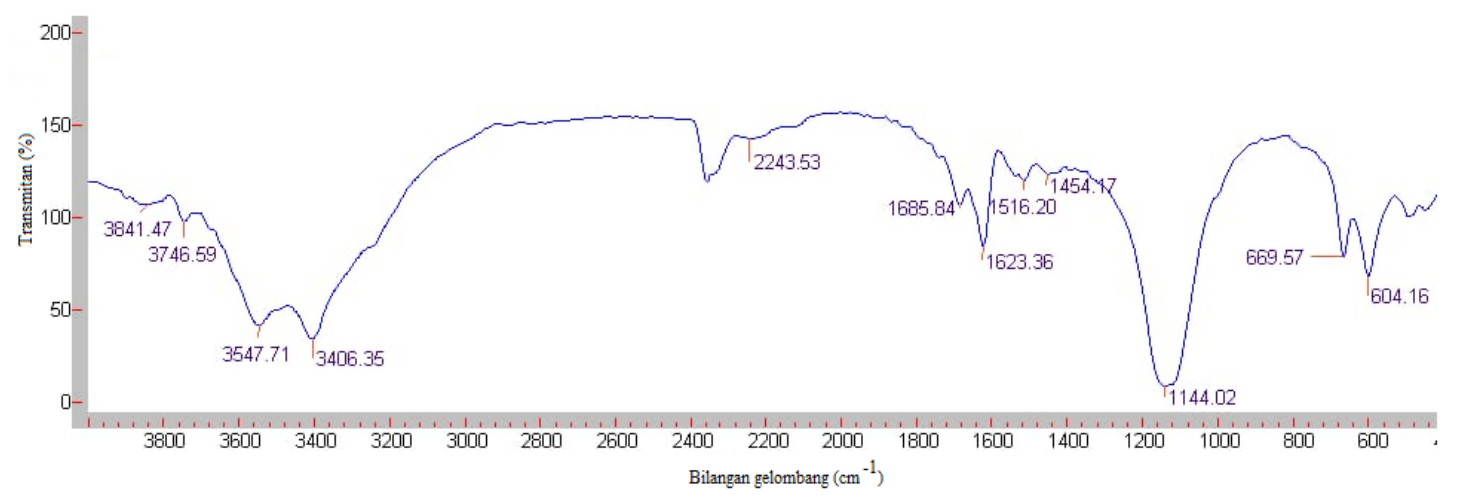

Gambar 3. Spektrum FTIR ekstrak senyawa eksopolisakarida Spirulina sp.

Data Gambar 3 menunjukkkan adanya senyawa sakarida yang didukung oleh data serapan uluran $\mathrm{O}$ - $\mathrm{H}$ pada daerah $3406,35 \mathrm{~cm}^{-1}$, uluran $\mathrm{C}=\mathrm{O}$ pada daerah $1623,36 \mathrm{~cm}^{-1}$, tekukan $\mathrm{CH}_{2}$ pada daerah $1454,17 \mathrm{~cm}^{-1}$, dan C - C pada daerah $1116,71 \mathrm{~cm}^{-1}$.

\section{Hasil Nilai IC50 dan Aktivitas Antioksidan}

Hasil dari ekstrak senyawa eksopolisakarida dari mikroalga Spirulina sp. kemudian dibuat formulasi dalam bentuk sediaan lotion. Ekstrak senyawa eksopolisakarida dari mikroalgaSpirulina sp. memiliki karakteristik yang khas sehingga pada formulasinya perlu diperoleh basis yang efektif untuk menghasilkan sediaan lotion dengan kestabilan yang baik. Formulasi dari lotion ekstrak senyawa eksopoliskarida kemudian dilakukan uji antioksidan menggunakan metode DPPH. Hasil dari nilai $\mathrm{IC}_{50}$ dan aktivitas antioksidan dapat dilihat pada Tabel 3.

Tabel 3. Hasil nilai $\mathrm{IC}_{50}$ dan aktivitas antioksidan

\begin{tabular}{llll}
\hline \multicolumn{1}{c}{ Perlakuan } & \multicolumn{1}{c}{ Konsentrasi } & \multicolumn{1}{c}{ IC $_{\text {50 }}(\mathbf{p p m})$} & Aktivitas Antioksidan \\
\hline Vitamin C & $8 \mathrm{ppm}, 6 \mathrm{ppm}, 4$ & $7,096 \mathrm{ppm}$ & Sangat kuat \\
Lotion F1 & ppm dan 2 ppm & $42,429 \mathrm{ppm}$ & Sangat kuat \\
Lotion F2 & & $35,986 \mathrm{ppm}$ & Sangat kuat \\
Lotion F3 & & $29,726 \mathrm{ppm}$ & Sangat kuat \\
\hline
\end{tabular}

doi: http://dx.doi.org/10.23960/aec.v5.i2.2020.p169-177 
Tabel 3 menunjukkan nilai $\mathrm{IC}_{50}$ dari sediaan lotion ekstrak senyawa eksopolisakarida F1 sebesar 42,429 ppm, F2 sebesar 35,986 ppm, dan F3sebesar 29,72 ppm, diidapatkan nilai IC $_{50}$ lotion $<50 \mathrm{ppm}$. Semakin kecil nilai $\mathrm{IC}_{50}$ yang didapat maka semakin tinggi kekuatan suatu senyawa yang bersifat antioksidan untuk melawan efektivitas DPPH sebagai radikal

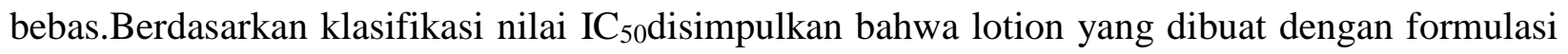
senyawa eksopolisakarida dari Spirulina sp. memiliki aktivitas antioksidan yang sangat kuat. Daya hambat terhadap radikal bebas DPPH diukur menggunakan spektrofotometer UV-Vis berdasarkan perubahan warna yang terjadi. DPPH (1,1-difenil-2-pikrilhidrazil) yang dilarutkan dengan metanol akan berwarna ungu, dan setelah bereaksi dengan sampel yang berperan sebagai antioksidan, akan berubah menjadi 1,1-difenil-2-pikrilhidrazin yang berwarna kuning. DPPH merupakan suatu radikal bebas yang stabil yang bila bereaksi dengan suatu zat yang dapat menyumbangkan hidrogen (antioksidan) akan tereduksi menjadi 1,1-difenil-2pikrilhidrazin(Molyneux, 2004)

\section{KESIMPULAN}

Lotion hasil formulasi dengan senyawa eksopolisakarida dari mikroalga Spirulina sp. memiliki potensi sebagai lotion yang bersifat antioksidan, dengan nilai $\mathrm{IC}_{50}$ yang dihasilkan dari lotion F1 sebesar 42,429 ppm, F2 sebesar 35,986 ppm, F3 sebesar 29,726 ppm. Nilai IC 50 lotion senyawa eksopolisakarida yang diperoleh termasuk jenis antioksidan yang memiliki aktivitas sangat kuat.

\section{DAFTAR PUSTAKA}

Anderson, R.A., 2005,Algal Culturing Technique, Elsevier Academic Press, London.

Barsanti, L, and Gualtieri, P. 2014,Algae Anatomy, Biochemistry and Biotechnology Second Edition, Taylor \& Francis Group, the academic division of T\&F Informa plc

Geresh, S., Mamontov, A. dan Weinstein, J. 2002, Sulfation of Extracellular Polysaccharides of red microalgae: preparation, characterization and properties,J Biochem. Biophys. Methods50 : Hlm. 179-187

Handayani, N. A. and Ariyanti, D., 2012, Potensi Mikroalga Sebagai Sumber Biomasa dan Pengembangan Produk Turunannya. Jurnal Teknik,33(2)-123.

doi: http://dx.doi.org/10.23960/aec.v5.i2.2020.p169-177 
Harutoshi, T, 2013,Exopolysaccharides of Lactic Acid Bacteria for Food and Colon Health Applications,licensee InTech.

Molyneux, .P. 2004.The Use of The Stable Free Radical Dyhenylpicrylhydrazil (DPPH) for Estimating Antioxidant Activity, Journals Science and Technology: 26, 211-219.

Nwodo, U. U., Green, E., and Okoh,A.I. 2012. Bacterial Exopolysaccharides: Functionality and Prospects,Int. J. Mol. Sci.13, 14002-14015.

Richmond, A., and Emeritus, 2013,Handbook of Microalgal Culture Applied Phycology and Biotechnology, Wiley-Blackwell.

Sajna, K. V., Sukumaran, R.K., Gottumukkala,L.D.,Jayamurthy,H. Dhar, K.S., PandeyA. 2013, Studies on Structural and Physical Characteristics of A Novel Exopolysaccharide from Pseudozyma sp. NII 08165,International Journal of Biological Macromolecules, 59, 8489.

Samarakon, K. and Jeon, Y.J. 2012,Bio-functionalities of proteins derived from marine algae A review, Food Research International, 48. 948-960.

Vonshak, A, 2002,Spirulina Platensis (Arthrospira) : Physiology, Cell-Biology and Biotechnology,Taylor and Francis e-library.

Winarsi, H, 2007, Antioksidan Alami dan Radikal Bebas Potensi dan Aplikasinya dalam Kesehatan, Yogyakarta, Kanisius.

Winahyu, D., A., 2017,Bioaktivitas Antioksidan Senyawa Eksopolisakarida Dari Mikroalga Dunaliella sp.,JFL: Jurnal Farmasi Lampung, 6(2) 